\title{
VEGF in nuclear medicine: Clinical application in cancer and future perspectives (Review)
}

\author{
SAMANTA TAURONE $^{1 *}$, FILIPPO GALLI $^{2 *}$, ALBERTO SIGNORE $^{2,5}$, ENZO AGOSTINELLI $^{3}$, \\ RUDI A.J.O. DIERCKX ${ }^{5}$, ANTONIO MINNI ${ }^{4}$, MARCELLA PUCCI ${ }^{4}$ and MARCO ARTICO ${ }^{4}$ \\ ${ }^{1}$ IRCCS-G.B. Bietti Foundation; ${ }^{2}$ Nuclear Medicine Unit, Department of Medical-Surgical Sciences and \\ Translational Medicine, Faculty of Medicine and Psychology, Departments of ${ }^{3}$ Biochemical Sciences 'A. Rossi Fanelli' \\ and ${ }^{4}$ Sensory Organs, 'Sapienza' University, Rome, Italy; ${ }^{5}$ Department of Nuclear Medicine and Molecular Imaging, \\ University of Groningen, University Medical Center Groningen, Groningen, The Netherlands
}

Received February 10, 2016; Accepted March 28, 2016

DOI: $10.3892 /$ ijo.2016.3553

\begin{abstract}
Clinical trials using antiangiogenic drugs revealed their potential against cancer. Unfortunately, a large percentage of patients does not yet benefit from this therapeutic approach highlighting the need of diagnostic tools to non-invasively evaluate and monitor response to therapy. It would also allow to predict which kind of patient will likely benefit of antiangiogenic therapy. Reasons for treatment failure might be due to a low expression of the drug targets or prevalence of other pathways. Molecular imaging has been therefore explored as a diagnostic technique of choice. Since the vascular endothelial growth factor (VEGF/VEGFR) pathway is the main responsible of tumor angiogenesis, several new drugs targeting either the soluble ligand or its receptor to inhibit signaling leading to tumor regression could be involved. Up today, it is difficult to determine VEGF or VEGFR local levels and their non-invasive measurement in tumors might give insight into the available target for VEGF/VEGFR-dependent antiangiogenic therapies, allowing therapy decision making and monitoring of response.
\end{abstract}

\section{Contents}

1. Introduction

2. Vascular endothelial growth factor (VEGF)

3. The VEGF/VEGFR pathway

4. VEGF and cancer related inflammation

5. Anti-VEGF drugs

Correspondence to: Professor Marco Artico, Department of Sensory Organs, 'Sapienza' University, V. le del Policlinico 155, I-00161 Rome, Italy

E-mail:marco.artico@uniroma1.it; t.samanta@yahoo.it

${ }^{*}$ Contributed equally

Key words: vascular endothelial growth factor, nuclear medicine, cancer, anti-VEGF therapies, angiogenesis
6. Efficacy of anti-VEGF therapy

7. Imaging of tumor angiogenesis

8. Targeting vascular endothelial growth factor (VEGF)

9. Targeting vascular endothelial growth factor receptor (VEGFR)

\section{Introduction}

Angiogenesis is the process that leads to the formation of new blood vessels, and, if induced by tumors, may also contribute to the growth of the disorganized vasculature able to sustain cancer progression over 2-3 $\mathrm{mm}$ and metastasis (1). The events that trigger tumor angiogenesis derive from the interaction between cancer cells and host microenvironment that includes immune cells, connective tissue and soluble factors. Vascular endothelial growth factor (VEGF) and its receptor (VEGFR) are the main contributors to proliferation of endothelial cells, thus representing suitable targets for antiangiogenic therapies (2).

\section{Vascular endothelial growth factor (VEGF)}

Vascular endothelial growth factor is the most important mediator of angiogenesis. It is overexpressed in various tumors, stimulating endothelial cell proliferation and migration, and leading to the formation of new blood vessels from pre-existing ones (3-8). The VEGF family is composed of five glycoproteins (VEGF-A, VEGF-B, VEGF-C, VEGF-D and VEGF-E). VEGF-A is a homodimeric, disulfide-bound glycoprotein, which exists in several isoforms with different numbers of amino acid residues, such as VEGF121, VEGF189 and VEGF165. Different VEGF-A isoforms exhibit varying biological properties, such as the ability to bind to cell surface heparin sulfate proteoglycans. VEGF121, commonly existing as a homodimer, is freely diffusible without heparin binding. The angiogenic actions of VEGF are mediated primarily via two closely related endothelium-specific receptor tyrosine kinases, Flt-1 (VEGFR1) and Flk-1/KDR (VEGFR2) (9). Both are largely restricted to vascular endothelial cells and are overexpressed on the endothelium of tumor vasculature, yet 
they are almost undetectable in the vascular endothelium of adjacent normal tissues (10). All of the VEGF-A isoforms bind to both VEGFR1 and VEGFR2.

VEGF and its receptors are overexpressed in a variety of solid tumor biopsy specimens, and overexpression of VEGFR2 or VEGF-A has been considered as a poor prognostic marker in various clinical studies (11-13). Indeed, new vasculature allows tumor cells to grow by supplying nutrients and oxygen, enabling disposal of metabolic waste products and providing a route for metastatic spreading. VEGF production by tumor cells is thought to be regulated by hypoxemia, growth factors signaling, cytokines, and cell differentiation (8).

Given the role of VEGF and VEGFR in several oncological and non-oncological diseases, pharmaceutical companies and researchers are deeply involved in developing agents potentially useful in the prevention of VEGF-A binding to its receptors (14), or antibodies blocking VEGFR2 (11) or small molecules that inhibit the kinase activity of VEGFR2 $(7,15)$ and thereby block growth factor signaling. Indeed, VEGF/VEGFR targeting has already been proved successful in many cancer types (16).

\section{The VEGF/VEGFR pathway}

VEGF-A and its receptors are the best-characterized signaling pathway in developmental angiogenesis as well as tumor angiogenesis (10). VEGFR2 appears to be the most important receptor in VEGF-induced mitogenesis, angiogenesis, and permeability increase, whereas the role of VEGFR1 in endothelial cell function is less clear (17). During the exponential growth stage, VEGFR expression is highly upregulated on the newly developed tumor vasculature. Being the naturally existing VEGFR ligand, VEGF121 offers several advantages over the synthetic small-molecule VEGFR ligands or antiVEGFR antibodies. It has much higher binding affinity to VEGFR (nanomolar range) than reported peptidic VEGFR inhibitors (submicromolar to micromolar range) $(18,19)$. If compared to antibody-based radiopharmaceuticals, VEGF121 clears much faster from the blood pool and the non-targeting organs because of its smaller size.

Regulation of inflammatory cell recruitment by VEGFR1 appears to be exerted mainly through placental growth factor (PGF). Notably, the expression of PGF is very low under physiological conditions, but it may be strongly upregulated in various cell types by different pathological stimuli such as hypoxia, inflammatory cytokines, or oncogenes (20-22). PGF has recently been regarded as an attractive candidate for antiangiogenic therapy. Indeed, it has been shown that PGF plays a key role in promoting pathological angiogenesis associated with tumor progression (23) and overexpression of PGF in a mouse melanoma model resulted in increased tumor growth and metastasis (24). Tumor cells may also express VEGFR2, although epithelial and mesenchymal tumor cells typically express VEGFR1 rather than VEGFR2 (25,26) (Fig. 1). Nevertheless, increased expression of VEGFR2 on tumor cells has been described for melanoma and hematological malignancies (27). It has been shown that VEGFR2-mediated signaling allowed survival of cancer cells under chronic hypoxic conditions and might contribute to a more aggressive phenotype (28) (Fig. 2).

\section{VEGF and cancer related inflammation}

Growing evidence supports an important link between chronic inflammation and tumor development. Induction of VEGFR2 expression in tumor cells, and also in intestinal epithelium during colitis, is mediated by the pro-inflammatory cytokine interleukin-6, which is a strong promoter of tumor growth in experimental colitis-associated colon cancer (29). A soluble form of the VEGFR2 (sVEGFR2) has been also described and may have important biological roles. sVEGFR2 binds VEGF-C and prevents activation of VEGFR3, consequently inhibiting lymphatic endothelial cell proliferation (30). Notably, regulation of sVEGFR2 in advanced metastatic neuroblastoma may promote lymphogenic spread of metastases (31). The expression of VEGFR3 in tumor cells is still controversial (32); however, it has been ascertained that inhibition of VEGFR3 activity arrests tumor vascularization, leading to decreased vascular density in several tumor models (33). The axis VEGFC/VEGFR3 plays a fundamental role in the tumor microenvironment by promoting the formation of new lymphatic vessels from pre-existing ones (34). VEGFC, produced by neoplastic cells, induces lymphatic endothelial destabilization, resulting in endothelial sprouting as well as leakage and enlargement of the vessels. These modifications induce entry of tumor cells into the lymphatics vessels and further dissemination of metastasis to sentinel lymph nodes $(35,36)$.

High expression of VEGFs and/or VEGFRs in various tumor biopsy specimens is indicative of poor prognosis for cancer patients $(2,37,38)$. Therefore, non-invasive imaging and quantification of VEGFR expression is of relevant importance in cancer patient management. Many strategies have been adopted to block the VEGF/VEGFR signaling pathway for cancer treatment, such as agents that can bind to VEGF-A to prevent its interaction with VEGFRs (such as bevacizumab, and VEGF-trap) $(39,40)$ antibodies/antibody fragments that target VEGFR-2 (ramucirumab, and CDP791) (41,42) and small molecule inhibitors that interrupt the downstream signaling of VEGFR-2 (axitinib, sunitinib, and sorafenib) $(43,44)$. Many of these agents have been approved by the Food and Drug Administration (FDA) for various medical indications in cancer therapy $(2,45)$.

VEGFR-2 mediates the majority of VEGF-A signaling in the tumor microenvironment including microvascular permeability and endothelial cell proliferation $(8,10)$. Several agents, including antibodies and soluble receptor constructs, have been developed to target the VEGF system. The drug that is currently most widely used in the clinical practice to modulate VEGF-A is the humanized monoclonal antibody. It blocks VEGF-induced endothelial cell proliferation, permeability, and survival, and it inhibits human tumor cell line growth. The likely mechanism is that bevacizumab binds to VEGF both soluble and bound to the extracellular matrix and thereby prevents VEGF binding to its receptors, blocking the biologic pathways induced after VEGF binding. Bevacizumab is approved both by the United States Food and Drug Administration (FDA) and the European Medicines Agency (EMA) for the treatment of metastatic colorectal cancer, non-small cell lung cancer, breast cancer and glioblastoma multiforme in combination with chemotherapy $(46,47)$. One of the greatest challenges in bevacizumab therapy is the lack of 


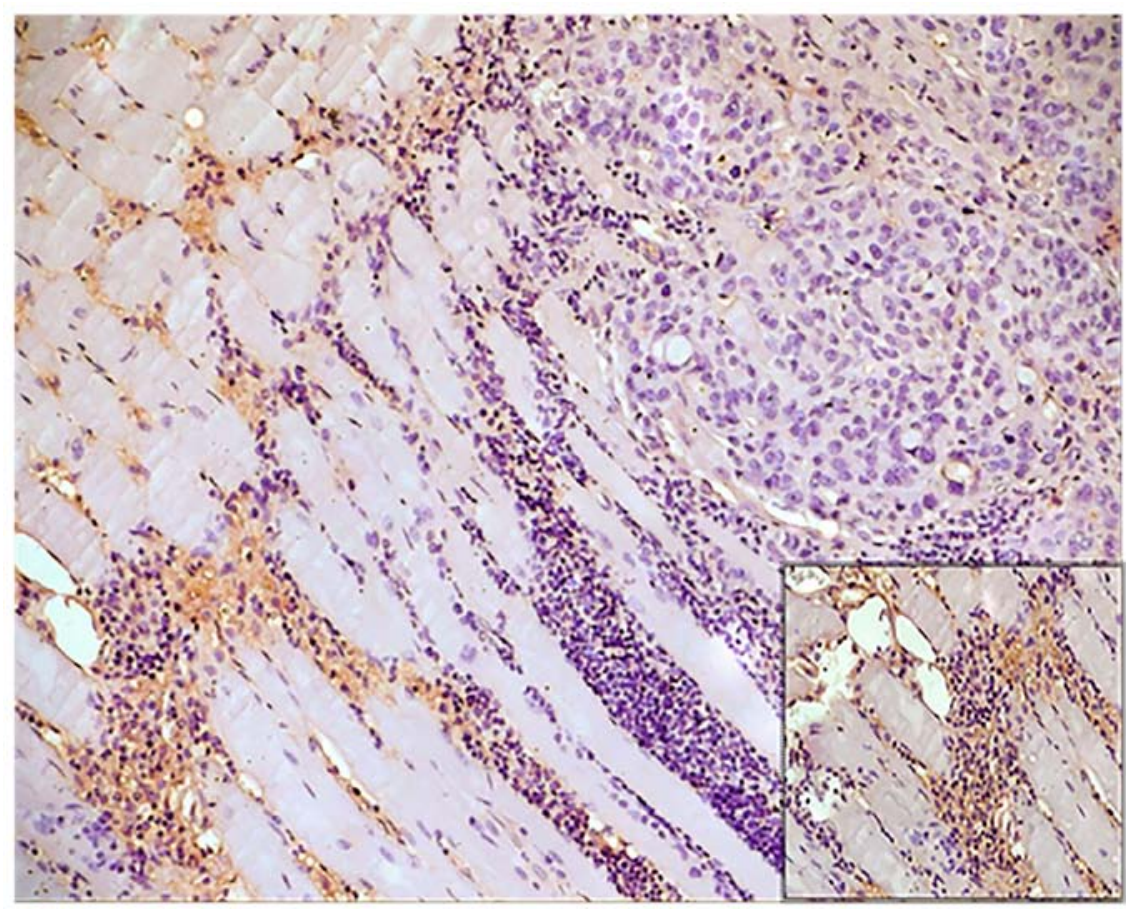

Figure 1. IHC analysis. Expression of VEGFR1 in mouse subcutaneous tissue implanted and colonized by human HT-29 colon carcinoma cells. VEGFR1 appears heterogeneously distributed between tumor cells (x10; boxed area, x20).

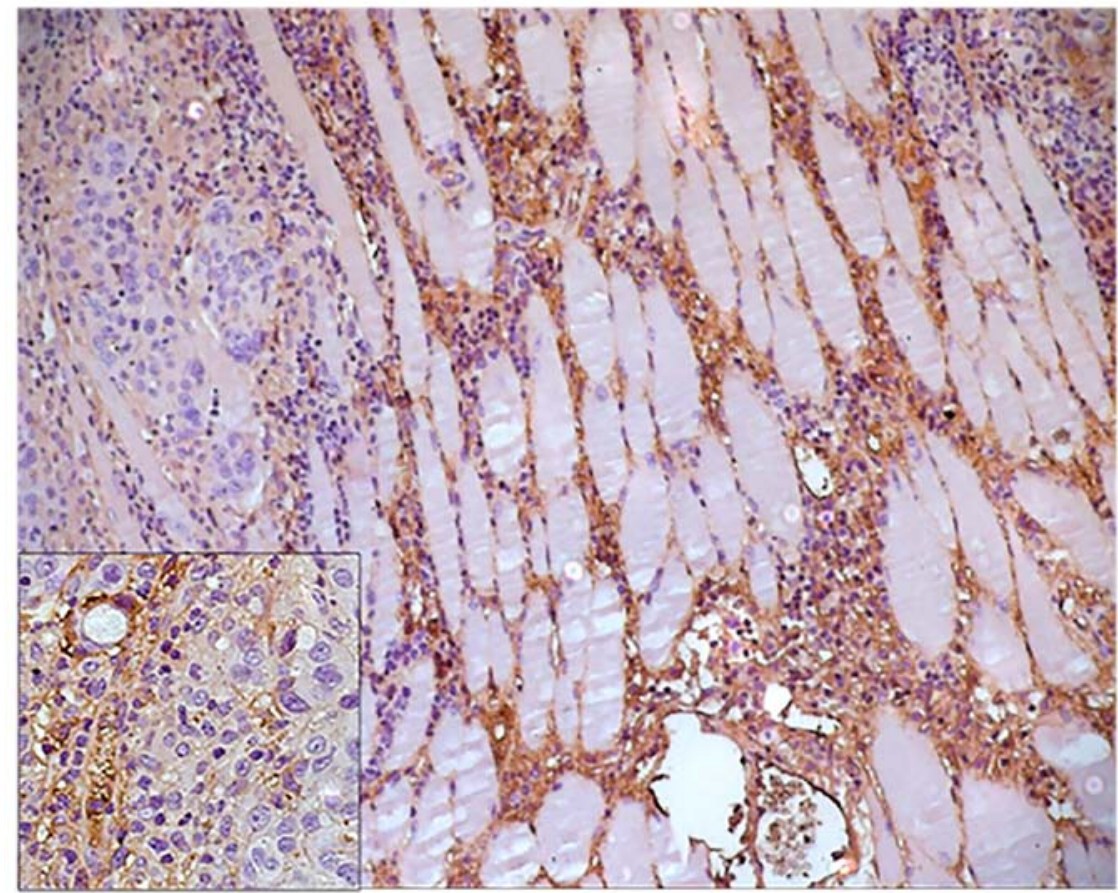

Figure 2. IHC analysis. Expression of VEGFR2 in mouse subcutaneous tissue implanted and colonized by human HT-29 colon carcinoma cells (x10). VEGFR2 immunoreactivity is present between tumor cells and it is particularly expressed in the wall of the blood vessels (boxed area, $\mathrm{x} 40$ ).

predictive biomarkers and tools that can predict the efficacy of anti-VEGF therapy (47).

\section{Anti-VEGF drugs}

Development of anti-angiogenic therapy including anti-VEGF antibodies and VEGF-tyrosine kinase receptors has been a major landmark in cancer therapy leading to improvement in survival in several cancers. The pharmacologic inhibition of angiogenesis via the VEGF pathway is an important therapeutic approach that prevents cancer growth and metastasis formation. In addition to anti-VEGF antibodies, other strategies have been explored and include the blocking of its signaling receptor, receptor tyrosine kinase inhibitors 
(16,48-50), and gene therapy approaches, in which the vector produces an antisense molecule or a soluble receptor that acts in a dominant-negative manner (51).

Several studies have shown that anti-VEGF treatment, in association with chemotherapy $(52)$ or radiation therapy $(53,54)$, results in greater antitumor effects than either treatment alone. An issue that is now being debated is the mechanism of such potentiation, and a variety of hypotheses, which are not mutually exclusive, have been put forward. Klement et al proposed that chemotherapy, especially when delivered at low dose, preferentially damages endothelial cells and the blockade of VEGF blunts a key survival signal for endothelial cells, thereby amplifying the antitumor-cell effects of chemotherapy (52). Jain suggested that antiangiogenic therapy 'normalizes' the tumor vasculature, leading to pruning of excessive endothelial cells and perivascular cells, reduction in vessel tortuosity and drop in interstitial pressure and consequent improved oxygenation and delivery of chemotherapy to tumor cells (55). These effects are accompanied by a reduction in permeability of macromolecules $(56,57)$. Willett et al have recently shown that VEGF blockade by bevacizumab decreases tumor perfusion, vascular volume, microvascular density, interstitial fluid pressure and the number of viable circulating endothelial and progenitor cells in colorectal cancer patients (58). Surprisingly, these studies have also shown that permeability to small molecules actually increases following VEGF blockade (58).

Bevacizumab was initially approved for the treatment of metastatic colorectal cancer in combination with intravenous 5-fluorouracil-based chemotherapy (59). Subsequently, bevacizumab was approved for various indications in non squamous cell lung carcinoma (NSCLC), metastatic renal cell carcinoma, and glioblastoma multiforme (38,60-63). The antitumor activity of bevacizumab is primarily manifested in combination with chemotherapy, except for renal cell carcinoma, where it has shown efficacy as a single agent (64). Presently, bevacizumab is being used in nearly 1,000 clinical trials, and despite promising results, its effects in many types of cancer are modest or even irrelevant (65). Furthermore, recent studies have raised the possibility that treatment with bevacizumab may be associated with a more aggressive invasive tumor phenotype, particularly in glioblastoma $(66,67)$, which is often a greatly vascularized brain tumor. Although the clinical impact of these results is far from clear, it is obvious that antiangiogenic therapy will have to be closely evaluated depending on disease stage and molecular profile of different patients and tumors. Preclinical data with anti-VEGFR2 antibodies have demonstrated a reduction in VEGF-induced signaling as well as angiogenesis and primary or metastatic growth in a variety of different tumor models $(7,68,69)$; therefore, the specific antibody-based blockade of VEGFR2 has also received special attention in clinical trials.

Ramucirumab (IMC-1121B; Imclone Systems) is currently being tested in several clinical trials, including breast cancer, gastric cancer, and HCC (70). Basing on preliminary results, this antibody has shown activity in patients previously treated with other antiangiogenic agents, suggesting a more efficient antitumor response by direct targeting of VEGFR2.

Small molecule inhibitors of VEGFR tyrosine kinase activity represent another major approach to blocking VEGFmediated angiogenesis. Several tyrosine kinase inhibitors have been developed to selectively inhibit VEGFR2, but they have also activity on other VEGFRs and tyrosine kinase receptors, including basic fibroblast growth factor (FGF) receptor, EGFR family members, PDGFR-a, PDGFR-b, c-kit, and Flt3. Sunitinib was approved in 2006 for its clinical use in imatinibresistant gastrointestinal stromal tumors and advanced metastatic renal cell carcinoma $(71,72)$, whereas sorafenib received FDA approval for the treatment of metastatic renal cell carcinoma (73) and HCC (74). Sunitinib and sorafenib have shown clinical efficacy as single agents, possibly due to their ability to inhibit multiple RTKs and in particular those regulating tumor angiogenesis. Additional clinical trials aimed to evaluate combinations of sorafenib and sunitinib with different chemotherapeutic agents and other antiangiogenic agents are under evaluation.

There has been a worldwide research program to develop antiangiogenic agents for the treatment of cancer. Many families of antiangiogenic drugs now exist, but their clinical development has been hampered by scarce data concerning the optimal biologically active dose. In addition, although the classical phase I study design focuses on toxicity as an endpoint to establish the maximum tolerated dose, many humanized monoclonal antibodies have no clinically significant toxicity, which precludes identification of the maximum tolerated dose. Furthermore, biologic dose-response relationships may follow a bell-shaped curve (75) and therefore the maximum tolerated dose may not even be the best dose for clinical applications. To overcome these issues, biologic pharmacodynamic investigations (76) have entered phase I clinical trial design with the goal of establishing the optimum biologically active dose.

\section{Efficacy of anti-VEGF therapy}

Antiangiogenic therapies are promising approaches for cancer treatment. However, their systematic application remains problematic because of poor understanding of mechanisms of action and occurrence of resistance (77). Indeed, a significant fraction of patients do not respond to antiangiogenic drugs (78), whereas those who respond have relatively modest benefits, mostly in progression-free survival rather than in overall survival. In addition, a number of significant toxicities have been observed in patients treated with antiangiogenic agents, emphasizing that a careful assessment of the risk-benefit ratio needs to be conducted in individual patients. Despite disease stabilization and increase in the proportion of patients with progression-free survival, tumors eventually become resistant to antiangiogenic agents and relapse (79-82).

Antiangiogenic therapy depends on several factors, including the tumor stage, the nature of the tumor vascular bed and the origin and genotype of the neoplastic cells. Tumorigenesis (17), and progression (83) are often associated with a modified expression of different angiogenic factors (83) (Figs. 3 and 4). Advanced human breast cancers may express different pro-angiogenic factors, including VEGF, acidic and basic fibroblast growth factors (aFGF and bFGF), transforming growth factor $\beta 1$ (TGF $\beta 1$ ), platelet-derived growth factor (PDGF), placental growth factor (PGF) and pleiotrophin (83). The mechanism of action of certain drugs is also different at various stages of tumorigenesis. For example, the 


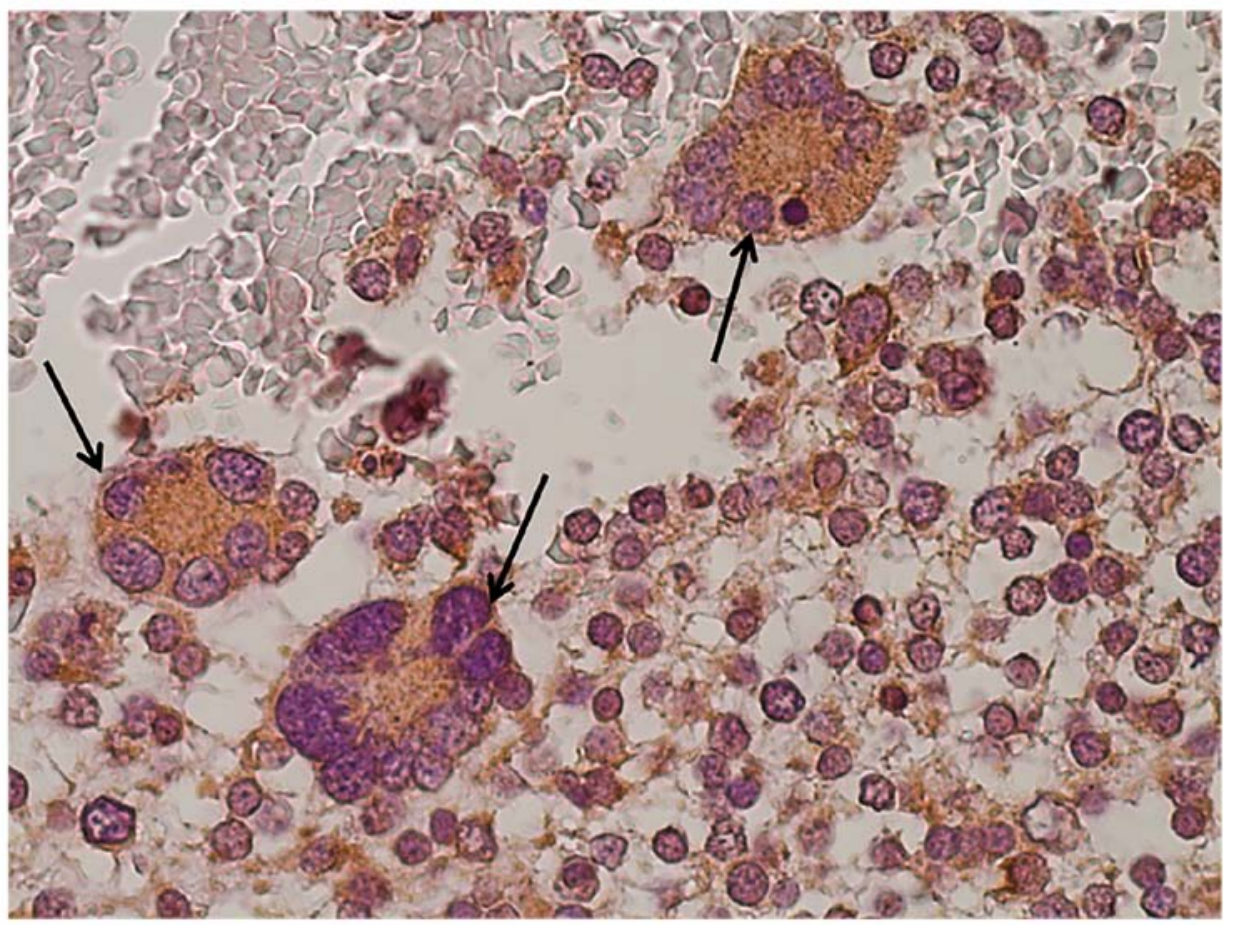

Figure 3. Immunohistochemical staining for VEGF-A in human glioblastoma (GBM) in a 7-year old patient. Numerous tumor cells show strong cytoplasmic staining for VEGF-A. Human GBM stem-like cells (giant multinucleated proliferating cells) form three typical rings (GBSCs) (x40).

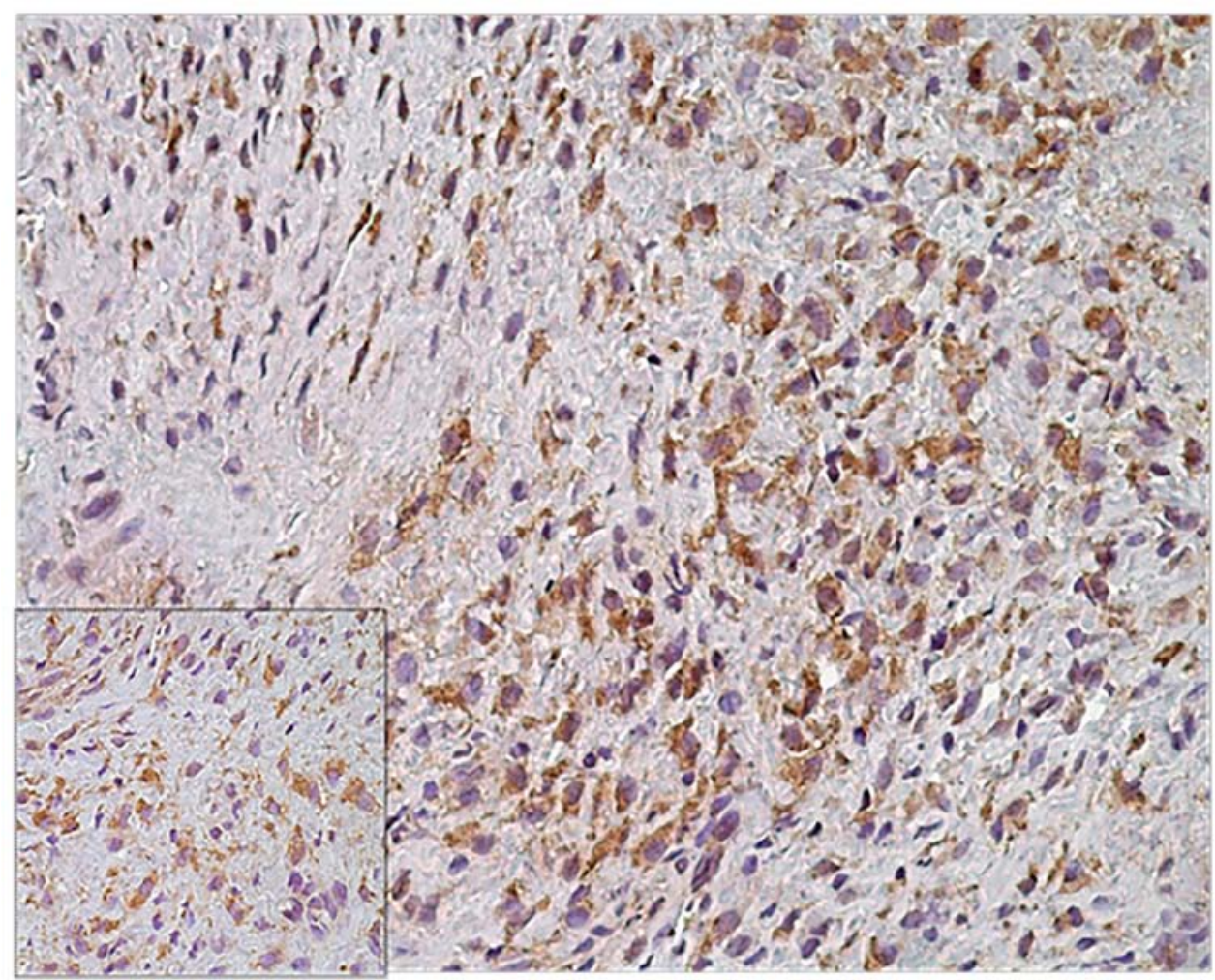

Figure 4. Immunohistochemical staining for VEGF-A in a case of nasopharyngeal angiofibroma (age of patient, 14 years). Marked immunoreactivity is visible in the fibrous tissue and in pathological vessels. IHC for VEGF demonstrates expression in $>50 \%$ of stromal cells (boxed area, $\mathrm{x} 40$ ).

release of VEGF, following the remodeling of the extracellular matrix by matrix metalloproteinase 9 (MMP9), is reported to be a component of the RIP1-Tag2 angiogenic switch (84-88).
Inhibition of VEGF is not effective against established $\beta$-cell islet tumors $(85,89)$, and this finding may lead to hypothesize that the vasculature matures with increased pericyte coverage, 
thereby reducing dependence on VEGF2. The success of targeted therapies, such as trastuzumab (Genentech), is often dependent on the expression of the drug target by the tumor (90). Given that bevacizumab is a monoclonal antibody with a well-defined target, VEGF2, it is logical that VEGF expression might predict benefit. However, in retrospective subset analyses, VEGF expression by primary tumors of metastatic, treatment-refractory breast cancers $(91,92)$ or metastatic colorectal cancers did not predict benefit from the addition of bevacizumab (93). The reasons responsible for this behavior are not entirely clear. Perhaps VEGF expression by primary tumors is not representative of metastatic disease, but detailed research indicates that they are equivalent (44).

\section{Imaging of tumor angiogenesis}

CT remains still a fundamental imaging technique in the diagnosis of neoplastic human pathologies. Positron emission tomography (PET), very sensitive technique (down to 10-12 molar) and quantitative with superb tissue penetration, has been widely used in clinical oncology for tumor staging and treatment monitoring, where ${ }^{18} \mathrm{~F}-\mathrm{FDG}$ was used as the tracer for measuring tumor glucose metabolism (47). Highresolution PET scanners continue to be developed and made available for imaging small animals, improving the capacity for in vivo studies in mice, primates, and humans.

As already discussed, antiangiogenic targeted therapies are a promising approach for the treatment of cancer. However, clinical trials showed variable response due to intra- and inter-tumor heterogeneity and non-invasive tools to monitor treatment response and drug efficacy are needed. Several methods have been developed to image tumor angiogenesis, but there is no general agreement as to which strategy is the most suitable for monitoring antiangiogenic therapy in singlecenter and multicenter trials. There is also evidence that angiogenic imaging data may be a useful predictor of response to chemo-radiotherapy, the success of which depends on good perfusion of the tumor. Personalized medicine allows to identify the suitable patient population for the appropriate therapy at the right time, as well as to provide quantitative, non-invasive, and accurate information on the therapeutic responses in real-time. In this scenario nuclear medicine offers several radiopharmaceuticals for 'in vivo' imaging of angiogenic markers, but to date, none emerged as a gold standard. As an example, radiolabeled bevacizumab is one of the most studied radiopharmaceuticals since it is able to bind VEGF with high affinity. Indeed, development of a bevacizumab-based imaging agent can play important roles in these aspects, as well as elucidating the function and modulation of VEGF/VEGFR signaling during cancer development/intervention.

\section{Targeting vascular endothelial growth factor (VEGF)}

Being the most important angiogenic effector and already established therapeutic target, many VEGF-targeting radiopharmaceuticals were developed and studied in vitro and in vivo. In particular, the $\mathrm{mAb}$ bevacizumab is one of the most studied radiolabelled anti-VEGF drugs and, to date, it has been labeled with a number of PET isotopes such 89Zr (94), 124I (95), 86Y (96), and 64Cu (97). In addition, it has also been investigated with various other imaging techniques such as single photon emission computed tomography (SPECT) (98), ultrasound (99), and optical imaging (100). Studies with radiolabeled bevacizumab for imaging tumor angiogenesis were performed in preclinical models proposing that its accumulation in the tumor was due to interactions with the VEGF-A-165 and -189 isoforms, associated with the tumor cell surface and/or the extracellular matrix $(101,102)$. However, in a clinical study with ${ }^{111}$ In-bevacizumab in patients affected by colorectal cancer liver metastases, there was a lack of correlation between radiolabeled bevacizumab uptake and VEGF-A expression in the lesions (103). Authors speculated that the accumulation of the mAb was due to enhanced vascular permeability leading to unspecific uptake in the tumor. This could limit the usefulness of radiolabeled bevacizumab in imaging tumor angiogenesis. However, this radiopharmaceutical showed promising results in many other cancers such as breast cancer. Various studies have reported overexpression of VEGF-A in the breast cancer microenvironment, compared with normal breast tissue (104-106). All VEGF-A splice variants are bound by the clinically used monoclonal antibody bevacizumab. When labeled with the PET isotope $89 \mathrm{Zr}$, it preserves its VEGF-A-binding properties. Thus, tracer dosages of radiolabeled bevacizumab can be used for tumor-specific, whole-body imaging of VEGF-A. In preclinical studies $(94,101)$ and in a study in renal cell cancer patients (107), we have already shown an excellent tumor-tobackground ratio with an optimum at $4 \mathrm{~d}$ after tracer injection when using $89 \mathrm{Zr}$-bevacizumab. $89 \mathrm{Zr}$-bevacizumab might be potentially valuable for biologic characterization of tumors and for prediction and evaluation of the effect of VEGF-Atargeting therapeutics. VEGF-A is reported in several studies to be over-expressed in malignant breast tumors and in ductal carcinoma in situ $(106,108)$, thus covering the full spectrum from early-stage breast cancer to more advanced stages. More frequent VEGF-A staining was found to be related to aggressiveness as assessed by VEGF-A staining in a study with 1,788 breast tumors (106). 89Zr-bevacizumab PET proved to be able to detect a broad range of VEGF-A expression levels. Quantitative tumor analyses showed a $>10$-fold difference between individual SUVmax measurements, suggesting large differences in VEGF-A tumor levels between patients, 89Zr-bevacizumab might be potentially valuable for biologic characterization of tumors and for prediction and evaluation of the effect of VEGF-A-targeting therapeutics. Because of better and more accurate scatter and attenuation corrections associated with PET, 86Y-labeled bevacizumab was developed for imaging VEGF-A tumor angiogenesis and as a surrogate marker for 90Y-based RIT. The ${ }^{111}$ In and 89Zr-labeled probes have been proposed as surrogate imaging markers for $90 \mathrm{Y}$ therapy, however, deviations were observed due to subtle differences in the metalchelate complexes and metabolism $(102,109)$ highlighting the need for the development of isotopically matched $86 \mathrm{Y}$-labeled probes for $90 \mathrm{Y}$. However, $86 \mathrm{Y}$ possesses its own set of challenges, in particular, its high positron energy (Emax 1/4 3.1 MeV) and emission of $1.08 \mathrm{MeV}$ (83\% abundance), which can significantly affect the image quality and recovery coefficients due to spurious coincidences. When appropriate corrections are performed, the image quality is greatly improved and is quantifiable $(110,111)$. 
PET imaging with 86Y-CHX-A00-DTPA-bevacizumab may have a useful role in patient selection for bevacizumabrelated therapy as it would indicate accessibility of the antibody to VEGF-A target sites. However, 86Y-CHX-A00-DTPAbevacizumab imaging by itself may not predict the response to therapy as it is only indicative of how much bevacizumab reaches the tumor and not the overall tumor microenvironment and the biomolecular characteristics. The primary use of 86Y-CHX-A00-DTPA-bevacizumab will be for the selection of patients for 90Y-CHX-A00-DTPA-bevacizumab RIT, monitoring of those patients during therapy as well as to provide information for dosimetry calculations $(102,112)$. To achieve the long-term goal of clinical translation of 86Y-CHX-A00DTPA-bevacizumab, PET/CT and MRI studies are currently being performed with mice bearing orthotopic and disseminated ascites forming colorectal and ovarian tumors.

In conclusion, the utility of 86Y-CHX-A00-DTPAbevacizumab for noninvasive PET imaging of VEGF-A secreting tumors in preclinical models has been demonstrated (96) 86Y-CHX-A00-DTPA-bevacizumab may be useful for the assessment of bevacizumab uptake and localization, which may be important for risk stratification, patient screening and appropriate dosage selection. Ultimately, 86Y-CHX-A00DTPA-bevacizumab would serve as a surrogate PET marker for dosimetry and selection of subjects for 90Y-CHX-A00-DTPAbevacizumab RIT of VEGF-A-secreting cancers (96). The limiting factor for more general application of imaging with radionuclides is the radiation burden. In a study comparing the risks of radiation-induced cancer from mammography, molecular breast imaging, and positron emitting mammography, the cumulative cancer incidence is 15-30 times higher for positron emission mammography and molecular breast imaging than for mammography (113). The estimated radiation burden of $89 \mathrm{Zr}$-bevacizumab-PET is $19 \mathrm{mSv}$ per tracer injection, on the basis of extrapolation from ${ }^{111} \mathrm{In}$-bevacizumab data and a dosimetry study on 89Zr-U36, compared with 5.3 $\mathrm{mSv}$ for ${ }^{18} \mathrm{~F}$-FDG PET (114-117). Besides bevacizumab, other radiolabeled anti-VEGF antibodies such as I-labeled VG76e (118) and HuMV833 (119) have been reported. Phase I trials of the latter revealed that antibody distribution and clearance was quite heterogeneous, not only between and within patients but also between and within individual tumors, which underscored the importance of patient selection to achieve maximum therapeutic effect.

\section{Targeting vascular endothelial growth factor receptor (VEGFR)}

In addition to VEGF, VEGFR is another important target for cancer diagnosis and monitoring the therapeutic efficacy of anti-angiogenic therapies. Over the last decade, imaging of VEGFR expression has gained enormous interest not only in cancer but also in many other angiogenesis-related diseases (120). Examination of the tumor in the same animals or cancer patients with both VEGF- and VEGFR-targeted radiopharmaceuticals or fluorescent probes may give important insight into the expression kinetics of VEGF and VEGFRs during cancer development and cancer therapy. Substantial effort has been devoted to non-invasive imaging of VEGFR expression in cancer over the last two decades and various agents have been developed for SPECT (120-122), PET $(121,123,124)$, optical imaging, magnetic resonance imaging (MRI) and ultrasound (US). Because of the high affinity to VEGFRs, VEGF121 has emerged as a particularly desirable candidate for tracer development in the literature (125). To avoid significant interference with VEGFR binding, site-specific labeling of VEGF-based proteins has been adopted in many literature reports which typically utilizes a cysteine residue for radiolabeling $(121,126)$. It is important to develop a PET tracer for the imaging of VEGFR expression using lysine tagged recombinant human VEGF121 (denoted as K3-VEGF121). The three lysine residues at the $\mathrm{N}$-terminus, far from the VEGFR binding sites, can facilitate radiolabeling without affecting the biological activity and receptor binding. In the design of novel radiotracers, it is important to minimize the radiation dose to normal organs without compromising the imaging characteristics.

\section{Acknowledgements}

This study was supported by NOBILE S.p.A. Thanks are also due to REGIONE LAZIO Prot. FILAS-RU-2014 - 1020 (E.A.).

\section{References}

1. Folkman J: Tumor angiogenesis: Therapeutic implications. N Engl J Med 285: 1182-1186, 1971.

2. Folkman J: Angiogenesis: An organizing principle for drug discovery? Nat Rev Drug Discov 6: 273-286, 2007.

3. Ellis LM, Liu W and Wilson M: Down-regulation of vascular endothelial growth factor in human colon carcinoma cell lines by antisense transfection decreases endothelial cell proliferation. Surgery 120: 871-878, 1996.

4. Gerber HP, Kowalski J, Sherman D, Eberhard DA and Ferrara N: Complete inhibition of rhabdomyosarcoma xenograft growth and neovascularization requires blockade of both tumor and host vascular endothelial growth factor. Cancer Res 60: 6253-6258, 2000.

5. Kim K J, Li B, Winer J, Armanini M, Gillett N, Phillips HS and Ferrara N: Inhibition of vascular endothelial growth factorinduced angiogenesis suppresses tumour growth 'in vivo'. Nature 362: 841-844, 1993.

6. Klohs WD and Hamby JM: Antiangiogenic agents. Curr Opin Biotechnol 10: 544-549, 1999.

7. Prewett M, Huber J, Li Y, Santiago A, O'Connor W, King K, Overholser J, Hooper A, Pytowski B, Witte L, et al: Antivascular endothelial growth factor receptor (fetal liver kinase 1) monoclonal antibody inhibits tumor angiogenesis and growth of several mouse and human tumors. Cancer Res 59: 5209-5218, 1999.

8. Ferrara $\mathrm{N}$ and Davis-Smyth T: The biology of vascular endothelial growth factor. Endocr Rev 18: 4-25, 1997.

9. Sato Y, Kanno S, Oda N, Abe M, Ito M, Shitara K and Shibuya M: Properties of two VEGF receptors, Flt-1 and KDR, in signal transduction. Ann NY Acad Sci 902: 201-205, 2000.

10. Ferrara N: The role of VEGF in the regulation of physiological and pathological angiogenesis. EXS 94: 209-231, 2005.

11. Tang RF, Itakura J, Aikawa T, Matsuda K, Fujii H, Korc M and Matsumoto Y: Overexpression of lymphangiogenic growth factor VEGF-C in human pancreatic cancer. Pancreas 22: 285-292, 2001.

12. Rydén L, Linderholm B, Nielsen NH, Emdin S, Jönsson PE and Landberg G: Tumor specific VEGF-A and VEGFR2/KDR protein are co-expressed in breast cancer. Breast Cancer Res Treat 82: 147-154, 2003.

13. Decaussin M, Sartelet H, Robert C, Moro D, Claraz C, Brambilla $\mathrm{C}$ and Brambilla E: Expression of vascular endothelial growth factor (VEGF) and its two receptors (VEGF-R1-Flt1 and VEGF-R2-Flk1/KDR) in non-small cell lung carcinomas (NSCLCs): Correlation with angiogenesis and survival. J Pathol 188: 369-377, 1999. 
14. Sun J, Wang DA, Jain RK, Carie A, Paquette S, Ennis E, Blaskovich MA, Baldini L, Coppola D, Hamilton AD, et al: Inhibiting angiogenesis and tumorigenesis by a synthetic molecule that blocks binding of both VEGF and PDGF to their receptors. Oncogene 24: 4701-4709, 2005.

15. Wood JM, Bold G, Buchdunger E, Cozens R, Ferrari S, Frei J, Hofmann F, Mestan J, Mett H, O'Reilly T, et al: PTK787/ZK 222584, a novel and potent inhibitor of vascular endothelial growth factor receptor tyrosine kinases, impairs vascular endothelial growth factor-induced responses and tumor growth after oral administration. Cancer Res 60: 2178-2189, 2000.

16. Wedge SR, Ogilvie DJ, Dukes M, Kendrew J, Curwen JO, Hennequin LF, Thomas AP, Stokes ES, Curry B, Richmond GH et al: ZD4190: An orally active inhibitor of vascular endothelial growth factor signaling with broad-spectrum antitumor efficacy. Cancer Res 60: 970-975, 2000.

17. Ferrara N: Vascular endothelial growth factor: Basic science and clinical progress. Endocr Rev 25: 581-611, 2004.

18. El-Mousawi M, Tchistiakova L, Yurchenko L, Pietrzynski G, Moreno M, Stanimirovic D, Ahmad D and Alakhov V: A vascular endothelial growth factor high affinity receptor 1-specific peptide with antiangiogenic activity identified using a phage display peptide library. J Biol Chem 278: 46681-46691, 2003.

19. Gonçalves M, Estieu-Gionnet K, Berthelot T, Laïn G, Bayle M, Canron X, Betz N, Bikfalvi A and Déléris G: Design, synthesis, and evaluation of original carriers for targeting vascular endothelial growth factor receptor interactions. Pharm Res 22: 1411-1421, 2005.

20. Failla CM, Odorisio T, Cianfarani F, Schietroma C, Puddu P and Zambruno G: Placenta growth factor is induced in human keratinocytes during wound healing. J Invest Dermatol 115: 388-395, 2000.

21. Green CJ, Lichtlen P, Huynh NT, Yanovsky M, Laderoute KR, Schaffner W and Murphy BJ: Placenta growth factor gene expression is induced by hypoxia in fibroblasts: A central role for metal transcription factor-1. Cancer Res 61: 2696-2703, 2001.

22. Larcher F, Franco M, Bolontrade M, Rodriguez-Puebla M, Casanova L, Navarro M, Yancopoulos G, Jorcano JL and Conti CJ: Modulation of the angiogenesis response through Ha-ras control, placenta growth factor, and angiopoietin expression in mouse skin carcinogenesis. Mol Carcinog 37: 83-90, 2003.

23. Carmeliet P, De Smet F, Loges S and Mazzone M: Branching morphogenesis and antiangiogenesis candidates: Tip cells lead the way. Nat Rev Clin Oncol 6: 315-326, 2009.

24. Li B, Sharpe EE, Maupin AB, Teleron AA, Pyle AL, Carmeliet P and Young PP: VEGF and PIGF promote adult vasculogenesis by enhancing EPC recruitment and vessel formation at the site of tumor neovascularization. FASEB J 20: 1495-1497, 2006.

25. Hicklin DJ and Ellis LM: Role of the vascular endothelial growth factor pathway in tumor growth and angiogenesis. J Clin Oncol 23: 1011-1027, 2005.

26. Podar K and Anderson KC: The pathophysiologic role of VEGF in hematologic malignancies: Therapeutic implications. Blood 105: 1383-1395, 2005.

27. Youssoufian H, Hicklin DJ and Rowinsky EK: Review: Monoclonal antibodies to the vascular endothelial growth factor receptor-2 in cancer therapy. Clin Cancer Res 13: S5544-S5548, 2007.

28. Calvani M, Rapisarda A, Uranchimeg B, Shoemaker RH and Melillo G: Hypoxic induction of an HIF-1alpha-dependent bFGF autocrine loop drives angiogenesis in human endothelial cells. Blood 107: 2705-2712, 2006.

29. Waldner MJ, Wirtz S, Jefremow A, Warntjen M, Neufert C, Atreya R, Becker C, Weigmann B, Vieth M, Rose-John S, et al: VEGF receptor signaling links inflammation and tumorigenesis in colitis-associated cancer. J Exp Med 207: 2855-2868, 2010.

30. Albuquerque RJC, Hayashi T, Cho WG, Kleinman ME, Dridi S, Takeda A, Baffi JZ, Yamada K, Kaneko H, Green MG, et al: Alternatively spliced vascular endothelial growth factor receptor-2 is an essential endogenous inhibitor of lymphatic vessel growth. Nat Med 15: 1023-1030, 2009.

31. Becker J, Pavlakovic H, Ludewig F, Wilting F, Weich HA, Albuquerque R, Ambati J and Wilting J: Neuroblastoma progression correlates with downregulation of the lymphangiogenesis inhibitor sVEGFR-2. Clin Cancer Res 16: 1431-1441, 2010.

32. Petrova TV, Bono P, Holnthoner W, Chesnes J, Pytowski B, Sihto H, Laakkonen P, Heikkilä P, Joensuu $\mathrm{H}$ and Alitalo K: VEGFR-3 expression is restricted to blood and lymphatic vessels in solid tumors. Cancer Cell 13: 554-556, 2008.
33. Laakkonen P, Waltari M, Holopainen T, Takahashi T, Pytowski B, Steiner P, Hicklin D, Persaud K, Tonra JR, Witte L, et al: Vascular endothelial growth factor receptor 3 is involved in tumor angiogenesis and growth. Cancer Res 67: 593-599, 2007.

34. He Y, Rajantie I, Ilmonen M, Makinen T, Karkkainen MJ, Haiko P, Salven P and Alitalo K: Preexisting lymphatic endothelium but not endothelial progenitor cells are essential for tumor lymphangiogenesis and lymphatic metastasis. Cancer Res 64: $3737-3740,2004$

35. Achen MG and Stacker SA: Targeting tumor stroma. Curr Cancer Drug Targets 8: 446, 2008.

36. He Y, Rajantie I, Pajusola K, Jeltsch M, Holopainen T, Yla-HerttualaS, Harding T, Jooss K, Takahashi T and Alitalo K: Vascular endothelial cell growth factor receptor 3-mediated activation of lymphatic endothelium is crucial for tumor cell entry and spread via lymphatic vessels. Cancer Res 65: 4739-4746, 2005.

37. Gerber HP and Ferrara N: Pharmacology and pharmacodynamics of bevacizumab as monotherapy or in combination with cytotoxic therapy in preclinical studies. Cancer Res 65: 671-680, 2005.

38. Sandler A, Gray R, Perry MC, Brahmer J, Schiller JH, Dowlati A, Lilenbaum R and Johnson DH: Paclitaxel-carboplatin alone or with bevacizumab for non-small-cell lung cancer. N Engl J Med 355: 2542-2550, 2006

39. Miles DW, Chan A, Dirix LY, Cortés J, Pivot X, Tomczak P, Delozier T, Sohn JH, Provencher L, Puglisi F, et al: Phase III study of bevacizumab plus docetaxel compared with placebo plus docetaxel for the first-line treatment of human epidermal growth factor receptor 2-negative metastatic breast cancer. J Clin Oncol 28: 3239-3247, 2010.

40. Robert NJ, Diéras V, Glaspy J, Brufsky AM, Bondarenko I, Lipatov ON, Perez EA, Yardley DA, Chan SY, Zhou X, et al: RIBBON-1: Randomized, double-blind, placebo-controlled, phase III trial of chemotherapy with or without bevacizumab for first-line treatment of human epidermal growth factor receptor 2 -negative, locally recurrent or metastatic breast cancer. J Clin Oncol 29: 1252-1260, 2011.

41. Miller K, Wang M, Gralow J, Dickler M, Cobleigh M, Perez EA, Shenkier T, Cella D and Davidson NE: Paclitaxel plus bevacizumab versus paclitaxel alone for metastatic breast cancer. N Engl J Med 357: 2666-2676, 2007.

42. Valachis A, Polyzos NP, Patsopoulos NA, Georgoulias V, Mavroudis D and Mauri D: Bevacizumab in metastatic breast cancer: A meta-analysis of randomized controlled trials. Breast Cancer Res Treat 122: 1-7, 2010.

43. Pivot X, Schneeweiss A, Verma S, Thomssen C, PassosCoelho JL, Benedetti G, Ciruelos E, von Moos R, Chang HT, Duenne AA, et al: Efficacy and safety of bevacizumab in combination with docetaxel for the first-line treatment of elderly patients with locally recurrent or metastatic breast cancer: Results from AVADO. Eur J Cancer 47: 2387-2395, 2011.

44. Vach W, Høilund-Carlsen PF, Fischer BM, Gerke O and Weber W: How to study optimal timing of PET/CT for monitoring of cancer treatment. Am J Nucl Med Mol Imaging 1: 54-62, 2011.

45. Rakheja R, Ciarallo A, Alabed YZ and Hickeson M: Intravenous administration of diazepam significantly reduces brown fat activity on 18F-FDG PET/CT. Am J Nucl Med Mol Imaging 1: 29-35, 2011.

46. Eary JF, Hawkins DS, Rodler ET and Conrad EUI III: (18)F-FDG PET in sarcoma treatment response imaging. Am J Nucl Med Mol Imaging 1: 47-53, 2011

47. Iagaru A: 18 F-FDG PET/CT: Timing for evaluation of response to therapy remains a clinical challenge. Am J Nucl Med Mol Imaging 1: 63-64, 2011.

48. Mendel DB, Schreck RE, West DC, Li G, Strawn LM, Tanciongco SS, Vasile S, Shawver LK and Cherrington JM: The angiogenesis inhibitor SU5416 has long-lasting effects on vascular endothelial growth factor receptor phosphorylation and function. Clin Cancer Res 6: 4848-4858, 2000.

49. Laird AD, Vajkoczy P, Shawver LK, Thurnher A, Liang C, Mohammadi M, Schlessinger J, Ullrich A, Hubbard SR, Blake RA, et al: SU6668 is a potent antiangiogenic and antitumor agent that induces regression of established tumors. Cancer Res 60: 4152-4160, 2000.

50. Drevs J, Hofmann I, Hugenschmidt H, Wittig C, Madjar H, Müller M, Wood J, Martiny-Baron G, Unger C and Marmé D: Effects of PTK787/ZK 222584, a specific inhibitor of vascular endothelial growth factor receptor tyrosine kinases, on primary tumor, metastasis, vessel density, and blood flow in a murine renal cell carcinoma model. Cancer Res 60: 4819-4824, 2000. 
51. Davidoff AM, Leary MA, Ng CY and Vanin EF: Gene therapymediated expression by tumor cells of the angiogenesis inhibitor flk-1 results in inhibition of neuroblastoma growth in vivo. J Pediatr Surg 36: 30-36, 2001

52. Klement G, Baruchel S, Rak J, Man S, Clark K, Hicklin DJ, Bohlen P and Kerbel RS: Continuous low-dose therapy with vinblastine and VEGF receptor-2 antibody induces sustained tumor regression without overt toxicity. J Clin Invest 105 R15-R24, 2000.

53. Lee CG, Heijn M, di Tomaso E, Griffon-Etienne G, Ancukiewicz M, Koike C, Park KR, Ferrara N, Jain RK, Suit HD, et al: Anti-Vascular endothelial growth factor treatment augments tumor radiation response under normoxic or hypoxic conditions. Cancer Res 60: 5565-5570, 2000

54. Kozin SV, Boucher Y, Hicklin DJ, Bohlen P, Jain RK and Suit HD Vascular endothelial growth factor receptor-2-blocking antibody potentiates radiation-induced long-term control of human tumor xenografts. Cancer Res 61: 39-44, 2001.

55. Jain RK: Normalizing tumor vasculature with anti-angiogenic therapy: A new paradigm for combination therapy. Nat Med 7: 987-989, 2001.

56. Yuan F, Chen Y, Dellian M, Safabakhsh N, Ferrara N and Jain RK: Time-dependent vascular regression and permeability changes in established human tumor xenografts induced by an anti-vascular endothelial growth factor/vascular permeability factor antibody. Proc Natl Acad Sci USA 93: 14765-14770, 1996.

57. Pham CD, Roberts TP, van Bruggen N, Melnyk O, Mann J, Ferrara N, Cohen RL and Brasch RC: Magnetic resonance imaging detects suppression of tumor vascular permeability after administration of antibody to vascular endothelial growth factor. Cancer Invest 16: 225-230, 1998.

58. Willett CG, Boucher Y, di Tomaso E, Duda DG, Munn LL, Tong RT, Chung DC, Sahani DV, Kalva SP, Kozin SV, et al: Direct evidence that the VEGF-specific antibody bevacizumab has antivascular effects in human rectal cancer. Nat Med 10 145-147, 2004

59. Hurwitz H, Fehrenbacher L, Novotny W, Cartwright $T$, Hainsworth J, Heim W, Berlin J, Baron A, Griffing S, Holmgren E, et al: Bevacizumab plus irinotecan, fluorouracil, and leucovorin for metastatic colorectal cancer. N Engl J Med 350: 2335-2342, 2004.

60. Escudier B, Bellmunt J, Négrier S, Bajetta E, Melichar B, Bracarda S, Ravaud A, Golding S, Jethwa S and Sneller V: Phase III trial of bevacizumab plus interferon alfa-2a in patients with metastatic renal cell carcinoma (AVOREN): Final analysis of overall survival. J Clin Oncol 28: 2144-2150, 2010.

61. Friedman HS, Prados MD, Wen PY, Mikkelsen T, Schiff D, Abrey LE, Yung WKA, Paleologos N, Nicholas MK, Jensen R, et al: Bevacizumab alone and in combination with irinotecan in recurrent glioblastoma. J Clin Oncol 27: 4733-4740, 2009.

62. Kreisl TN, Kim L, Moore K, Duic P, Royce C, Stroud I, Garren N, Mackey M, Butman JA, Camphausen K, et al: Phase II trial of single-agent bevacizumab followed by bevacizumab plus irinotecan at tumor progression in recurrent glioblastoma. J Clin Oncol 27: 740-745, 2009

63. Rini BI, Halabi S, Rosenberg JE, Stadler WM, Vaena DA, Ou SS, Archer L, Atkins JN, Picus J, Czaykowski P, et al: Bevacizumab plus interferon alfa compared with interferon alfa monotherapy in patients with metastatic renal cell carcinoma: CALGB 90206. J Clin Oncol 26: 5422-5428, 2008

64. Yang JC, Haworth L, Sherry RM, Hwu P, Schwartzentruber DJ, Topalian SL, Steinberg SM, Chen HX and Rosenberg SA: A randomized trial of bevacizumab, an anti-vascular endothelial growth factor antibody, for metastatic renal cancer. N Engl J Med 349: 427-434, 2003.

65. Van Meter ME and Kim ES: Bevacizumab: Current updates in treatment. Curr Opin Oncol 22: 586-591, 2010.

66. Keunen O, Johansson M, Oudin A, Sanzey M, Rahim SA, Fack F Thorsen F, Taxt T, Bartos M, Jirik R, et al: Anti-VEGF treatment reduces blood supply and increases tumor cell invasion in glioblastoma. Proc Natl Acad Sci USA 108: 3749-3754, 2011.

67. Artico M,CervoniL, Celli P, Salvati M and Palma L: Supratentorial glioblastoma in children: A series of 27 surgically treated cases. Childs Nerv Syst 9: 7-9, 1993

68. Bruns CJ, Shrader M, Harbison MT, Portera C, Solorzano CC, Jauch KW, Hicklin DJ, Radinsky R and Ellis LM: Effect of the vascular endothelial growth factor receptor-2 antibody DC101 plus gemcitabine on growth, metastasis and angiogenesis of human pancreatic cancer growing orthotopically in nude mice. Int J Cancer 102: 101-108, 2002.
69. Shaheen RM, Tseng WW, Vellagas R, Liu W, Ahmad SA, Jung YD, Reinmuth N, Drazan KE, Bucana CD, Hicklin DJ, et al: Effects of an antibody to vascular endothelial growth factor receptor- 2 on survival, tumor vascularity, and apoptosis in a murine model of colon carcinomatosis. Int J Oncol 18: 221-226, 2001.

70. Spratlin J: Ramucirumab (IMC-1121B): Monoclonal antibody inhibition of vascular endothelial growth factor receptor-2. Curr Oncol Rep 13: 97-102, 2011.

71. Demetri GD, van Oosterom AT, Garrett CR, Blackstein ME, Shah MH, Verweij J, McArthur G, Judson IR, Heinrich MC, Morgan JA, et al: Efficacy and safety of sunitinib in patients with advanced gastrointestinal stromal tumour after failure of imatinib: A randomised controlled trial. Lancet 368: 1329-1338, 2006.

72. Motzer RJ, Michaelson MD, Rosenberg J, Bukowski RM, Curti BD, George DJ, Hudes GR, Redman BG, Margolin KA and Wilding G: Sunitinib efficacy against advanced renal cell carcinoma. J Urol 178: 1883-1887, 2007.

73. Escudier B, Eisen T, Stadler WM, Szczylik C, Oudard S, Siebels M, Negrier S, Chevreau C, Solska E, Desai AA, et al; TARGET Study Group: Sorafenib in advanced clear-cell renalcell carcinoma. N Engl J Med 356: 125-134, 2007.

74. Llovet JM, Ricci S, Mazzaferro V, Hilgard P, Gane E, Blanc JF, de Oliveira AC, Santoro A, Raoul JL, Forner A, et al; SHARP Investigators Study Group: Sorafenib in advanced hepatocellular carcinoma. N Engl J Med 359: 378-390, 2008.

75. Gruber BL, Marchese MJ and Kew R: Angiogenic factors stimulate mast-cell migration. Blood 86: 2488-2493, 1995.

76. Thomas AL, Morgan B, Drevs J, Jivan A, Buchert M, Horsfield M, et al: Pharmacodynamic results using dynamic contrast enhanced magnetic resonance imaging of 2 Phase 1 studies of the VEGF inhibitor PTK787/ZK 222584 in patients with liver metastases from colorectal cancer. Proc ASCO 20: 279, 2001.

77. Jain RK, Duda DG, Clark JW and Loeffler JS: Lessons from phase III clinical trials on anti-VEGF therapy for cancer. Nat Clin Pract Oncol 3: 24-40, 2006.

78. Burris H III and Rocha-Lima C: New therapeutic directions for advanced pancreatic cancer: Targeting the epidermal growth factor and vascular endothelial growth factor pathways. Oncologist 13: 289-298, 2008.

79. Bergers G and Hanahan D: Modes of resistance to anti-angiogenic therapy. Nat Rev Cancer 8: 592-603, 2008.

80. Ellis LM and Hicklin DJ: Pathways mediating resistance to vascular endothelial growth factor-targeted therapy. Clin Cancer Res 14: 6371-6375, 2008.

81. Kerbel RS: Tumor angiogenesis. N Engl J Med 358: 2039-2049, 2008.

82. Shojaei F and Ferrara N: Role of the microenvironment in tumor growth and in refractoriness/resistance to anti-angiogenic therapies. Drug Resist Updat 11: 219-230, 2008.

83. RelfM,LeJeune S,ScottPA,Fox S, Smith K, Leek R,Moghaddam A, Whitehouse R, Bicknell R and Harris AL: Expression of the angiogenic factors vascular endothelial cell growth factor, acidic and basic fibroblast growth factor, tumor growth factor $\beta-1$, plateletderived endothelial cell growth factor, placenta growth factor, and pleiotrophin in human primary breast cancer and its relation to angiogenesis. Cancer Res 57: 963-969, 1997.

84. Christofori G, Naik P and Hanahan D: Vascular endothelia growth factor and its receptors, flt-1 and flk-1, are expressed in normal pancreatic islets and throughout islet cell tumorigenesis. Mol Endocrinol 9: 1760-1770, 1995.

85. Inoue M, Hager JH, Ferrara N, Gerber HP and Hanahan D: VEGF-A has a critical, nonredundant role in angiogenic switching and pancreatic $\beta$ cell carcinogenesis. Cancer Cell 1: 193-202, 2002 .

86. Joyce JA, Laakkonen P, Bernasconi M, Bergers G, Ruoslahti E and Hanahan D: Stage-specific vascular markers revealed by phage display in a mouse model of pancreatic islet tumorigenesis. Cancer Cell 4: 393-403, 2003.

87. Bergers G, Javaherian K, Lo KM, Folkman J and Hanahan D: Effects of angiogenesis inhibitors on multistage carcinogenesis in mice. Science 284: 808-812, 1999.

88. Bergers G, Brekken R, McMahon G, Vu TH, Itoh T, Tamaki K, Tanzawa K, Thorpe P, Itohara S, Werb Z, et al: Matrix metalloproteinase-9 triggers the angiogenic switch during carcinogenesis. Nat Cell Biol 2: 737-744, 2000.

89. Bergers G, Song S, Meyer-Morse N, Bergsland E and Hanahan D: Benefits of targeting both pericytes and endothelial cells in the tumor vasculature with kinase inhibitors. J Clin Invest 111: $1287-1295,2003$ 
90. Slamon DJ, Leyland-Jones B, Shak S, Fuchs H, Paton V, Bajamonde A, Fleming T, Eiermann W, Wolter J, Pegram M, et al: Use of chemotherapy plus a monoclonal antibody against HER2 for metastatic breast cancer that overexpresses HER2. N Engl J Med 344: 783-792, 2001.

91. Hillan KJ: The role of VEGF expression in response to bevacizumab plus capcitabine in metastatic breast cancer (MBC). J Clin Oncol 21: S284, 2003.

92. Gobbi G, Mirandola P, Micheloni C, Solenghi E, Sponzilli I, Artico M, Soda G, Zanelli G, Pelusi G, Fiorini T, et al: Expression of HLA class I antigen and proteasome subunits LMP-2 and LMP-10 in primary vs. metastatic breast carcinoma lesions. Int J Oncol 25: 1625-1629, 2004.

93. Jubb AM, Hurwitz HI, Bai W, Holmgren EB, Tobin P, Guerrero AS, Kabbinavar F, Holden SN, Novotny WF, Frantz GD, et al: Impact of vascular endothelial growth factor-A expression, thrombospondin-2 expression, and microvessel density on the treatment effect of bevacizumab in metastatic colorectal cancer. J Clin Oncol 24: 217-227, 2006.

94. Nagengast WB, de Korte MA, Oude Munnink TH, TimmerBosscha H, den Dunnen WF, Hollema H, de Jong JR, Jensen MR, Quadt C, Garcia-Echeverria C, et al: 89Zr-bevacizumab PET of early antiangiogenic tumor response to treatment with HSP90 inhibitor NVP-AUY922. J Nucl Med 51: 761-767, 2010.

95. Christoforidis JB, Carlton MM, Knopp MV and Hinkle GH: PET/CT imaging of I-124-radiolabeled bevacizumab and ranibizumab after intravitreal injection in a rabbit model. Invest Ophthalmol Vis Sci 52: 5899-5903, 2011.

96. Nayak TK, Garmestani K, Baidoo KE, Milenic DE and Brechbiel MW: PET imaging of tumor angiogenesis in mice with VEGF-A-targeted (86)Y-CHX-A"-DTPA-bevacizumab. Int J Cancer 128: 920-926, 2011.

97. Paudyal B, Paudyal P, Oriuchi N, Hanaoka H, Tominaga $H$ and Endo K: Positron emission tomography imaging and biodistribution of vascular endothelial growth factor with $64 \mathrm{Cu}$-labeled bevacizumab in colorectal cancer xenografts. Cancer Sci 102: $117-121,2011$

98. Nagengast WB, Hooge MN, van Straten EM, Kruijff S, Brouwers AH, den Dunnen WF, de Jong JR, Hollema H, Dierckx RA, Mulder NH, et al: VEGF-SPECT with ${ }^{111}$ In-bevacizumab in stage III/IV melanoma patients. Eur J Cancer 47: 1595-1602, 2011.

99. Zhang L, Xu JS, Sanders VM, Letson AD, Roberts CJ and Xu RX: Multifunctional microbubbles for image-guided antivascular endothelial growth factor therapy. J Biomed Opt1 5: 030515,2010

100. Terwisscha van Scheltinga AG, van Dam GM, Nagengast WB, Ntziachristos V, Hollema H, Herek JL, Schröder CP, Kosterink JG, Lub-de Hoog MN and de Vries EG: Intraoperative near-infrared fluorescence tumor imaging with vascular endothelial growth factor and human epidermal growth factor receptor 2 targeting antibodies. J Nucl Med 52: 1778-1785, 2011.

101. Nagengast WB, de Vries EG, Hospers GA, Mulder NH, de Jong JR, Hollema H, Brouwers AH, van Dongen GA, Perk LR and Lub-de Hooge MN: In vivo VEGF imaging with radiolabeled bevacizumab in a human ovarian tumor xenograft. J Nucl Med 48: 1313-1319, 2007.

102. Helisch A, Förster GJ, Reber H, Buchholz HG, Arnold R, Göke B, Weber MM, Wiedenmann B, Pauwels S, Haus U, et al: Pre-therapeutic dosimetry and biodistribution of 86Y-DOTAPhe1-Tyr3-octreotide versus 111In-pentetreotide in patients with advanced neuroendocrine tumours. Eur J Nucl Med Mol Imaging 31: 1386-1392, 2004.

103. Scheer MG, Stollman TH, Boerman OC, Verrijp K, Sweep FC, Leenders WP, Ruers TJ and Oyen WJ: Imaging liver metastases of colorectal cancer patients with radiolabelled bevacizumab: Lack of correlation with VEGF-A expression. Eur J Cancer 44: $1835-1840,2008$

104. Vogl G, Bartel H, Dietze O and Hauser-Kronberger C: HER2 is unlikely to be involved in directly regulating angiogenesis in human breast cancer. Appl Immunohistochem Mol Morphol 14: $138-145,2006$.

105. Kostopoulos I, Arapantoni-Dadioti P, Gogas H, Papadopoulos S, Malamou-Mitsi V, Scopa CD, Markaki S, Karagianni E, Kyriakou V, Margariti A, et al: Evaluation of the prognostic value of HER-2 and VEGF in breast cancer patients participating in a randomized study with dose-dense sequential adjuvant chemotherapy. Breast Cancer Res Treat 96: 251-261, 2006.
106. Liu Y, Tamimi RM, Collins LC, Schnitt SJ, Gilmore HL, Connolly JL and Colditz GA: The association between vascular endothelial growth factor expression in invasive breast cancer and survival varies with intrinsic subtypes and use of adjuvant systemic therapy: Results from the Nurses' Health Study. Breast Cancer Res Treat 129: 175-184, 2011.

107. Oosting SF, Brouwers AH, Van Es SC, Nagengast WB, Oude Munnink TH, Lub-de Hooge MN, Hollema H, de Jong JR, de Jong IJ, de Haas S, et al: 89Zr-bevacizumab PET imaging in metastatic renal cell carcinoma patients before and during antiangiogenic treatment. J Clin Oncol 30 (Suppl): 10581, 2012.

108. BluffJE,Menakuru SR,Cross SS, Higham SE, Balasubramanian SP Brown NJ, Reed MW and Staton CA: Angiogenesis is associated with the onset of hyperplasia in human ductal breast disease. $\mathrm{Br} \mathbf{J}$ Cancer 101: 666-672, 2009.

109. Perk LR, Visser OJ, Stigter-van Walsum M, Vosjan MJ, Visser GW, Zijlstra JM, Huijgens PC and van Dongen GA: Preparation and evaluation of (89)Zr-Zevalin for monitoring of (90)Y-Zevalin biodistribution with positron emission tomography. Eur J Nucl Med Mol Imaging 33: 1337-1345, 2006.

110. Herzog H, Tellmann L, Scholten B, Coenen HH and Qaim SM: PET imaging problems with the non-standard positron emitters Yttrium-86 and Iodine-124. Q J Nucl Med Mol Imaging 52: $159-165,2008$.

111. Buchholz HG, Herzog H, Förster GJ, Reber H, Nickel O, Rösch F and Bartenstein P: PET imaging with yttrium-86: Comparison of phantom measurements acquired with different PET scanners before and after applying background subtraction. Eur J Nucl Med Mol Imaging 30: 716-720, 2003.

112. Palm S, Enmon RM Jr, Matei C, Kolbert KS, Xu S, Zanzonico PB, Finn RL, Koutcher JA, Larson SM and Sgouros G: Pharmacokinetics and biodistribution of (86)Y-Trastuzumab for (90)Y dosimetry in an ovarian carcinoma model: Correlative MicroPET and MRI. J Nucl Med 44: 1148-1155, 2003.

113. O'Connor MK, Li H, Rhodes DJ, Hruska CB, Clancy CB and Vetter RJ: Comparison of radiation exposure and associated radiation-induced cancer risks from mammography and molecular imaging of the breast. Med Phys 37: 6187-6198, 2010.

114. De Jong JR, Warnders FJ, Nagengast WB, Dierckx RAJO, Hospers GAP, Brouwers AH, De Vries EGE and De Hooge MN: Radiation dosimetry of ${ }^{111}$ In-bevacizumab for VEGF-SPECT in melanoma patients. Eur J Nucl Med Mol Imaging 37 (Suppl): S477-S477, 2010.

115. Börjesson PK, Jauw YW, de Bree R, Roos JC, Castelijns JA, Leemans CR, van Dongen GA and Boellaard R: Radiation dosimetry of 89Zr-labeled chimeric monoclonal antibody U36 as used for immuno-PET in head and neck cancer patients. $J$ Nucl Med 50: 1828-1836, 2009.

116. Murano T, Minamimoto R, Senda M, Uno K, Jinnouchi S, Fukuda H, Iinuma T, Tsukamoto E, Terauchi T, Yoshida T, et al: Radiation exposure and risk-benefit analysis in cancer screening using FDG-PET: Results of a Japanese nationwide survey. Ann Nucl Med 25: 657-666, 2011

117. Gaykema SB, Brouwers AH, Lub-de Hooge MN, Pleijhuis RG, Timmer-Bosscha H, Pot L, van Dam GM, van der Meulen SB, de Jong JR, Bart J, et al: 89Zr-bevacizumab PET imaging in primary breast cancer. J Nucl Med 54: 1014-1018, 2013.

118. Collingridge DR, Carroll VA, Glaser M, Aboagye EO, Osman S, Hutchinson OC, Barthel H, Luthra SK, Brady F, Bicknell R, et al: The development of [(124)I]iodinated-VG76e: A novel tracer for imaging vascular endothelial growth factor in vivo using positron emission tomography. Cancer Res 62: 5912-5919, 2002 .

119. Jayson GC, Zweit J, Jackson A, Mulatero C, Julyan P, Ranson M, Broughton L, Wagstaff J, Hakannson L, Groenewegen G, et al; European Organisation for Research and Treatment of Cancer Biological Therapeutic Development Group: Molecular imaging and biological evaluation of HuMV833 anti-VEGF antibody: Implications for trial design of antiangiogenic antibodies. J Natl Cancer Inst 94: 1484-1493, 2002.

120. Chan C, Sandhu J, Guha A, Scollard DA, Wang J, Chen P, Bai K, Lee L and Reilly RM: A human transferrin-vascular endothelial growth factor (hnTf-VEGF) fusion protein containing an integrated binding site for (111)In for imaging tumor angiogenesis. J Nucl Med 46: 1745-1752, 2005.

121. Backer MV, Levashova Z, Patel V, Jehning BT, Claffey K, Blankenberg FG and Backer JM: Molecular imaging of VEGF receptors in angiogenic vasculature with single-chain VEGFbased probes. Nat Med 13: 504-509, 2007. 
122. Blankenberg FG, Backer MV, Levashova Z, Patel V and Backer JM: In vivo tumor angiogenesis imaging with sitespecific labeled (99m)Tc-HYNIC-VEGF. Eur J Nucl Med Mol Imaging 33: 841-848, 2006.

123. Wang H, Cai W, Chen K, Li ZB, Kashefi A, He L and Chen X: A new PET tracer specific for vascular endothelial growth factor receptor 2. Eur J Nucl Med Mol Imaging 34: 2001-2010, 2007.

124. Hsu AR, Cai W, Veeravagu A, Mohamedali KA, Chen K, Kim S, Vogel H, Hou LC, Tse V, Rosenblum MG, et al: Multimodality molecular imaging of glioblastoma growth inhibition with vasculature-targeting fusion toxin VEGF121/rGel. J Nucl Med 48: 445-454, 2007.
125. Cai $\mathrm{W}$ and Chen X: Multimodality imaging of vascular endothelial growth factor and vascular endothelial growth factor receptor expression. Front Biosci 12: 4267-4279, 2007.

126. Backer MV and Backer JM: Imaging key biomarkers of tumor angiogenesis. Theranostics 2: 502-515, 2012. 